Pediat. Res. 5: 70-76 (1971)

Developmental biochemistry liver

\title{
Induction of Tyrosine- $\alpha$-Ketoglutarate Transaminase in Fetal Rat and Fetal Human Liver in Organ Culture
}

\author{
N. C. R. Rä̈hй ${ }^{[341}$, A. L. Schwartz ${ }^{[33]}$, and M. G. Lindroos \\ Departments of Medical Chemistry and of Obstetrics and Gynecology, University of Helsinki, Helsinki, Finland
}

\section{Extract}

Explants of fetal rat ( 13 days to term) and fetal human liver (crown to rump length $=$ 9-20 cm) were grown in organ culture. The survival of the explants was examined by histological appearance, mitotic index, and incorporation of precursors of ribonucleic acid (RNA), deoxyribonucleic acid (INA), and protein. Tissues adjusted to the culture system by the 24 th $\mathrm{hr}$ and remained so throughout the duration of the experiments. A slight increase in tyrosine transaminase activity occurred in control explants during the 3-day period in culture. Eighteen-hour incubation with hydrocortisone $\left(10^{-6} \mathrm{M}\right)$, glucagon $(5-25 \mu \mathrm{g} / \mathrm{ml})$, and insulin $(0.05-0.5 \mathrm{U} / \mathrm{ml})$ increased tyrosine transaminase levels, $3.1-6.5,2.5$, and 2.3 times the control values, respectively, in 18day to term fetal rat liver explants. Actinomycin $\mathrm{D}$ and cycloheximide completely inhibited the corticosteroid stimulation. Thirteen-day fetal rat liver exhibited no increase in tyrosine transaminase activity after hydrocortisone incubation for $24 \mathrm{hr}$, whereas glucagon plus dibutyryl cyclic adenosine monophosphate (AMP) did stimulate tyrosine transaminase activity twofold at this developmental stage. No increase in human fetal liver tyrosine transaminase occurred with any of the agents tested.

\section{Speculation}

These studies support the hypothesis that mammalian liver is incompetent to respond to hormone-induced enzyme synthesis before a certain developmental stage is reached.

\section{Introduction}

Tyrosine transaminase (I-tyrosine:2-oxoglutarate aminotransferase, TTA, EC. 2.6.1.5) has very low activity in fetal rat liver, but beginning with the 2 nd hr after birth there is a rapid increase in activity reaching a maximum at $12 \mathrm{hr}$, as shown by Sereni et al. [17]. These authors were not able to induce TTA activity by hydrocortisone injected into rat fetuses in utero, although a later study by Yeung $e t$ al. [21] indicated that if fetuses close to tern are exposed to corticosteroid for $10 \mathrm{hr}$ or more a marked elevation of T"TA activity can be observed in the liver. Greengard [3] has shown that the administration of glucagon, adrenalin, and cyclic AMP to fetal rats during the last 2 days of gestation evoked the appearance of TTA activity in vito. Stuclies in vitro on fetal rat liver maintained in organ culture $[19,20]$ demon. strated that the activity of TTA is elevated by cyclic MMP and by hormones (glucagon and catecholamine) which stimulate formation of this nucleotide, as well as by hydrocortisone and insulin in fetal liver near term. 
Kretchmer et al. [12], in a study of the development of the activity of the tyrosine-oxidizing system of human liver, found that adult liver has 10-30 times greater, and the liver of the full term newborn infant 3-5 times greater activity than the liver of a premature infant. No studies of the regulatory mechanisms involved in the developmental process of TTA in human liver have been presented in the literature to our knowledge. Since in the future, artificial stimulation of enzyme development during fetal life may facilitate certain metabolic adjustments of the premature and full term newborn infant to extrauterine existence, we have undertaken a comparative study of the development of TTA in fetal rat and fetal human liver maintained in organ culture with reference to the stage of development at which hormonal induction can be evoked.

\section{Materials and Methods}

Actinomycin D and cycloheximide were obtained commercially [22, 30], as were insulin and glucagon [23]; hydrocortisone [24]; triamcinolone [25]; cyclic AMP and $\mathrm{N}^{6}, \mathrm{O}^{2 \prime}$-dibutyryl cyclic $\mathrm{AMP}[26]$; and ${ }^{14} \mathrm{C}$-orotic acid (30-50 $\mathrm{mCi} / \mathrm{mmole})$, ${ }^{3} \mathrm{H}$-leucine $(>5000 \mathrm{mCi} /$ mmole), and ${ }^{3} \mathrm{H}$-thymidine $(>10,000 \mathrm{mCi} / \mathrm{mmole})$ [27].

The culture medium was Eagle's minimum essential medium in Hank's balanced salt solution with twice the normal concentrations of glucose and bicarbonate and with 100 units penicillin and $100 \mu \mathrm{g}$ streptomy$\operatorname{cin} / \mathrm{ml}[28]$.

\section{Animals, Tissue Preparation, and Organ Culture}

Adult female rats of a Sprague-Dawley strain [28] were mated for a 16 -hr period, so that the predicted time of conception was $\pm 8 \mathrm{hr}$. At the appropriate time of gestation the mother was killed by a blow to the head, and the entire uterus was quickly removed. All of the following procedures were carried out under sterile conditions. The livers of the fetuses were immediately excised and placed in petri dishes containing the culture medium. All hepatic tissue from litters of the same gestational age was pooled and cut into pieces $1 \mathrm{~mm}$ per side using injection needles and were randomly placed on lens paper strips supported by stainless steel grids to allow the lower surface of the explants to be in contact with the medium [18]. Each petri dish contained two grids of 20 pieces each and 10 ml medium. The dishes were placed in high humiclity chambers maintained at $+37^{\circ}$ with a circulating gas phase of $95 \%$ air $+5 \% \mathrm{CO}_{2}$. Hepatic tissue from human fetuses with a gestational age of 14-24 weeks (crown to rump length $9-20 \mathrm{~cm}$ ) were obtained at legal therapeutic abortions. The same preparative techniques as for rat tissues were used for human tissues. The human explants, however, were maintained with a gas phase of $95 \% \mathrm{O}_{2}+5 \% \mathrm{CO}_{2}$.

All explants were maintained in culture at least 40 hr before the experiments began. The condition of the explants was examined by the following means: histological appearance after embedding, sectioning, and staining with hematoxylin eosin; the mitotic index and the incorporations of radioactive precursors for protein ( ${ }^{3} \mathrm{H}$-leucine), RNA ( ${ }^{14} \mathrm{C}$-orotic acid), and DNA $\left({ }^{3} \mathrm{H}\right.$-thymidine). All incorporations were performed with 1-hr pulses in each culture dish, with one grid removed after $5 \mathrm{~min}$ and considered as a blank. The pulses used were as follows: $1 \mu \mathrm{Ci} / \mathrm{ml}$ medium for ${ }^{4} \mathrm{C}$-orotic acid and ${ }^{3} \mathrm{H}$-thymidine, and $0.5 \mu \mathrm{Ci} / \mathrm{ml}$ for ${ }^{3} \mathrm{H}$-leucine.

We could not successfully maintain postnatal liver tissues with our system.

\section{Analytical Methods}

The activity of TTA was determined according to the procedure of Diamondstone [1]. The same substrate concentrations were used for all fetal and adult analyses ( $12 \mathrm{~mm} \alpha$-ketoglutarate, $48 \mu \mathrm{M}$ pyridoxal phosphate, $2.4 \mathrm{~mm}$ diethyldithiocarbamate, $2.4 \mathrm{~mm}$ tyrosine, in 0.1 м $\left.\mathrm{KH}_{2} \mathrm{PO}_{4}\right)$. Approximately 40 pieces of liver were used for each enzyme assay. Enzyme activity has been expressed in units ( $1 \mu \mathrm{g} p$-hydroxyphenylpyruvate formed $/ \mathrm{hr}$ at $37^{\circ}$ ). The soluble protein concentration was measured by the method of Lowry $e t$ al. [13] with bovine serum albumin as a standard. The activity measured with this assay was proportional to time of incubation and amount of enzyme used. Incorporations of the RNA, DNA, and protein precursors ( ${ }^{14}$ C-orotic acid, ${ }^{3} \mathrm{H}$-thymidine, and ${ }^{3} \mathrm{H}$-leucine, respectively) were determined by spotting $50 \mu \mathrm{l}$ of a homogenate containing the tissue from one culture grid in 200 $\mu \mathrm{l}$ cold $0.13 \mathrm{M} \mathrm{KCl}$ on filter paper discs by a modification of the technique of Mans and Novelli [14]. The samples were then precipitated with $5 \%$ trichloroacetic acid and rinsed twice with ethanol after which they were dried and counted in a liquid spectrophotometer [29] in vials containing $0.5 \mathrm{ml}$ Hyamine [29] and $10 \mathrm{ml}$ POPOP (0.01\% 1, 4-bis-2, 4-methyl-5-phenyloxazolylbenzene) and PPO (0.4\% 2,5-diphenyloxizole in toluene). 


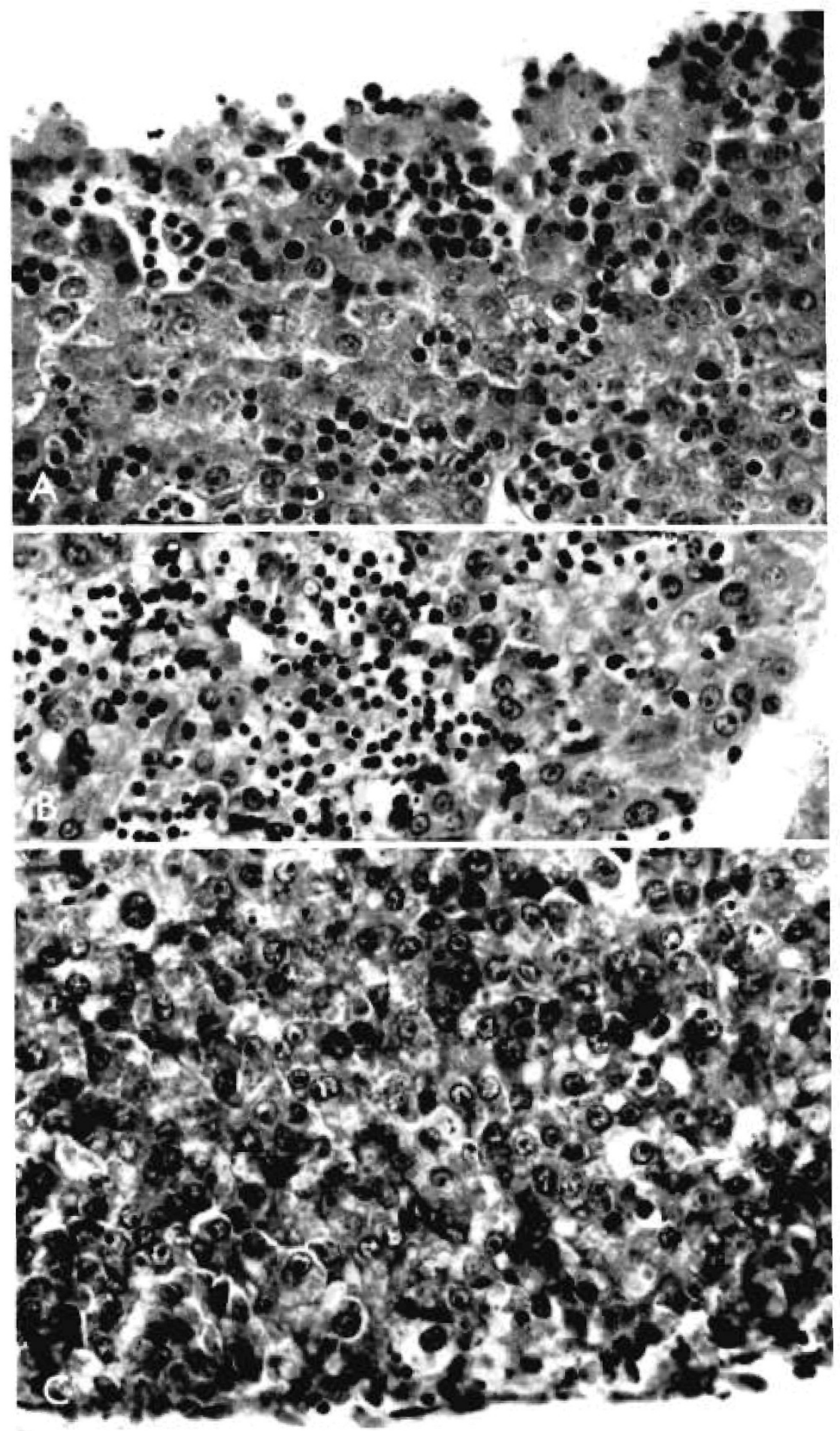

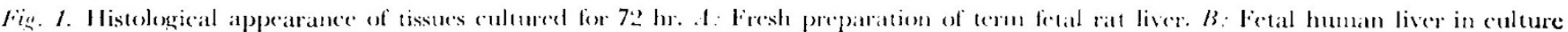

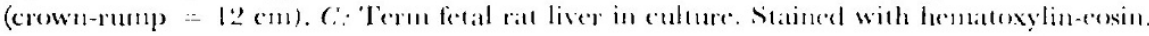




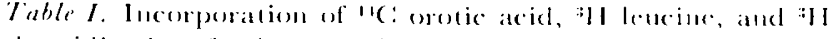
thymidine intofetal rat and fetal human liver in orgat culture

\begin{tabular}{|c|c|c|c|}
\hline \multirow[t]{2}{*}{ Liver } & 14 C Orotic acid $^{\circ}$ & "II-J.eucine & "H-Thrmisline \\
\hline & & clim/mp protein & \\
\hline $\begin{array}{l}\text { Rat (48 hr in } \\
\text { culture) }\end{array}$ & $\begin{array}{c}3480 \pm(12) \pm 0 \\
(12)^{1}\end{array}$ & $\begin{array}{c}22 t i() \pm 6(30) \\
(10)\end{array}$ & $\begin{array}{c}i 832 \pm 1(x) \\
\text { (i) }\end{array}$ \\
\hline $\begin{array}{r}\text { Human (39-48 } \\
\text { hrin culture) }\end{array}$ & $\begin{array}{c}10: 20 \pm 1 \cdot 17 \\
(12)\end{array}$ & $\begin{array}{c}1: 3013 \pm 185 \\
\text { (1i) }\end{array}$ & $\begin{array}{c}36) \pm 2(1) \\
(7)\end{array}$ \\
\hline
\end{tabular}

${ }^{1}$ Mean \pm sk, with number of observations in parentheses.

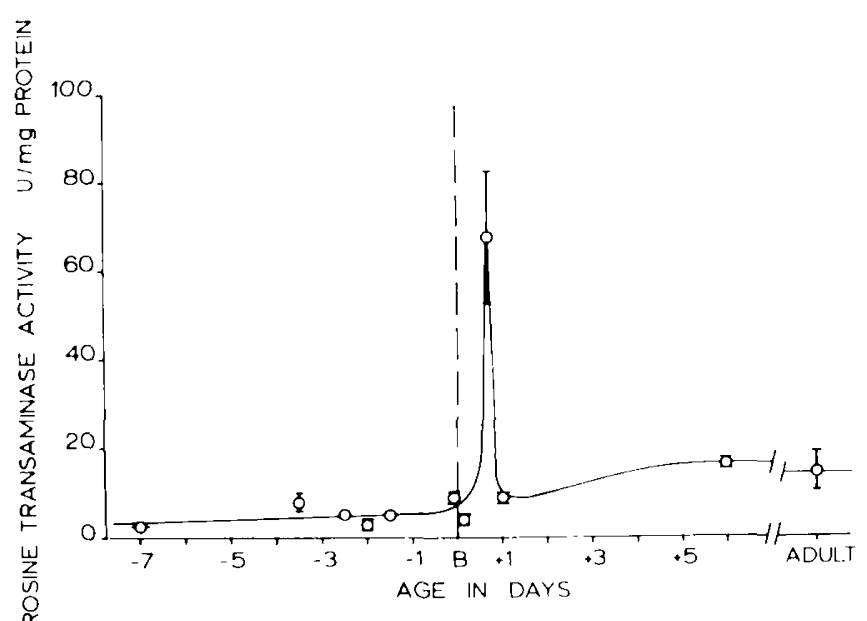

fig. 2. Development of crosine tramsaminase activity in the rate lach point repesents the mean \pm sf of at least thee animals.

\section{Resultis}

\section{Exaluation of the Organ Cinllure}

The histological study of the tissues indicated that throughout a 72 -hr culture period the appearance of the hepatocytes did not change although a disappearance of erythrocytes and hematopoietic cells could be noted (Fig. 1).

Incorporation of radioactive precursors for DNA, RNAL, and protein showed that the tissue remained functional throughout the period of the experiments. As seen from Table l, there was somewhat greater incorporation of ${ }^{11}$ C-orotic acid, ${ }^{3} \mathrm{H}$-leucine, and ${ }^{3} \mathrm{H}$ thymidine into the rat tissue explants than into the human. The incorporation of ${ }^{14} \mathrm{C}$-orotic acid and ${ }^{3} \mathrm{H}$ leucine into the fetal rat liver explitnts did not valy markedly during the culture period. As seen in Table I, very litte "H-thymidine was incorporated into the fetal tissue during a 1-hr pulse; however, when the labeling time was extended to $2.1 \mathrm{hr}$, a mean incorporation of about $3000 \mathrm{cmm} / \mathrm{mg}$ protein was found. An examination of the fetal lat liver explants after is he in culture revealed at mitotic index of o.ti"d, whereas a control liver at the time of excision hatd a mitotic index of $1.9 \%$

\section{Derelofmeme in lizes of Tyosine Transaminase detiy-} ity

Figure? illustrates the nomal development of T"TA activity in rat liver. During fetal life the activity was rery low, but soon after birth a rapid increase in rela activity was noted. $\Delta t 16 \mathrm{hr}$ after birth the enzyme activity was about eight times as high as before birth but decreased again rapidly to attain within 8 hr an activity similar to that foumd at birth. After this tansient rapid increase in activity a slow increase to about two times the fetal values was olserved during the following 5 postnatal days. This activity range was also found in adult rats.

The activity of TTA in the human fetal livers at 1. - 2.t weeks of gestation was somewhat vatriable and was approximately twice that found in fetal rat livers. In the liver from a $1.000-\mathrm{g}$ prematture inlant who died at 12 hr of age, the 'T"l h activity wats approximately awice that found in the fetuses. In this catse the liver sample was removed within 2 hr after death.

\section{Induction of Tyessine Transaminase in Organ ciul- ture?}

In fetal rat liver explants in culture the ITTA actisity increased slightly cluring the culure period, as seen

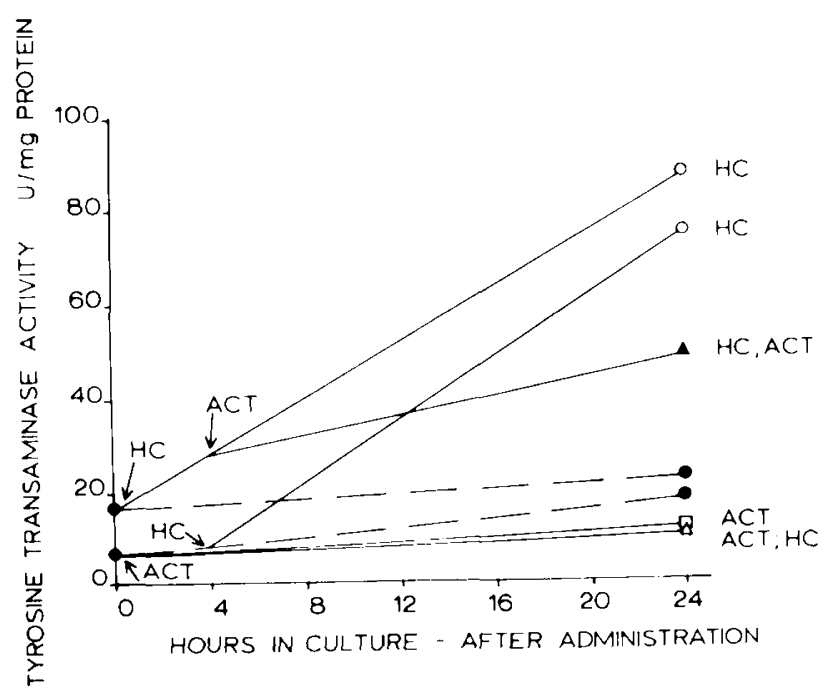

fig. 3. Heftect of actinomycin 1) on hedrocortisone-induced tyrosinc transaminase activity in term rat liver explants. batch point represents the arerage of two pallalled deteminations. The experiments were begun after $40 \mathrm{hr}$ in culture - : combol. $\mathrm{O}: \mathrm{Hy}$ drocontisone. $\square$ : Actinomycin 1). $\triangle$ : Actinomecin 1) followed by

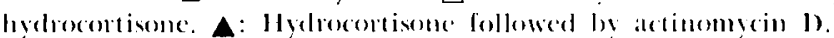




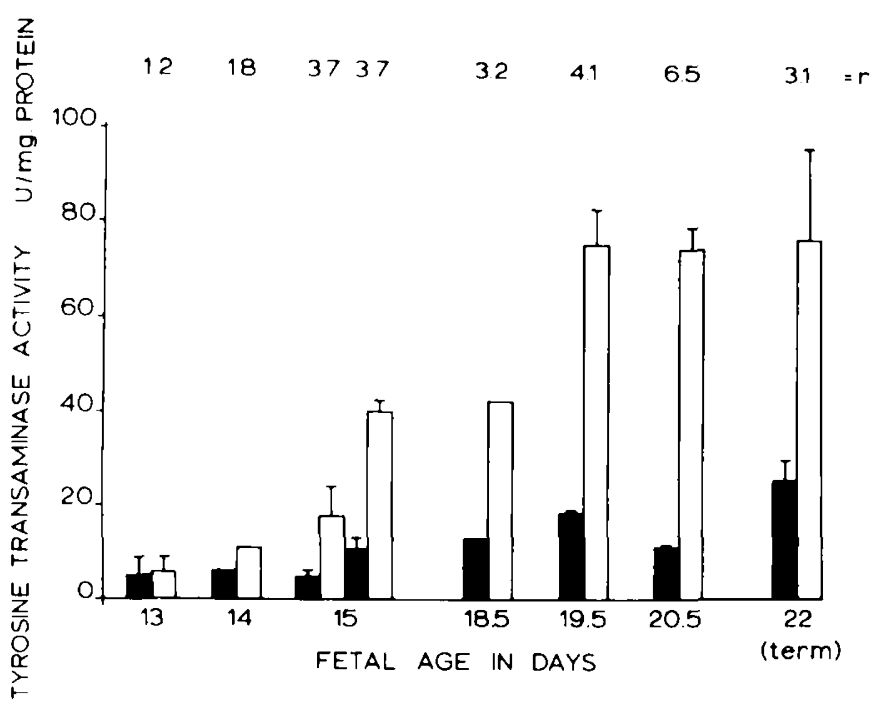

Fig. t. Development of hydrocortisone induction of rat liver tyrosine transaminase activity in culture. Open bars: Hydrocortisone. Closed bars: Controls. Standard deviations are given for more than awo deteminations. Ages are $\pm 8 \mathrm{hr} ; r=$ hydrocortisone/control. All experiments began after to he in culture and lasted 20 ()-21 hr. Bolh sets of data at dily 15 have identical $r$ vilues.

Table II. Effect of developmental age on induction of T'T.L activity by insulin, glucagon, and cyclic .MPP in fetal rat liver in organ culture'

\begin{tabular}{|c|c|c|c|}
\hline & \multicolumn{3}{|c|}{ Induction of $\Gamma \mathrm{TS}$ activity, units $/ \mathrm{mg}$ protein } \\
\hline & 1.3 days & 15 days & 22 days \\
\hline Control & 4.5 & $\begin{array}{c}4.8 \\
(3.1-6.5)\end{array}$ & 19.4 \\
\hline $\begin{array}{l}\text { Insulin, } 0.050 .5 \\
\mathrm{U} / \mathrm{nul}\end{array}$ & & $\begin{array}{c}8.6 \\
(7.8-9.4)\end{array}$ & $44.8 \pm 16.6$ \\
\hline $\begin{array}{l}\text { Gilucagom, } 525) \\
\mu \mathrm{g} / \mathrm{ml}\end{array}$ & & $\begin{array}{c}7.6 \\
(6.8 \cdot 8.3)\end{array}$ & $50.2 \pm 3.7$ \\
\hline $\begin{array}{l}\text { Glucagon, 5 } \mu \mathrm{g} / \\
\quad \mathrm{ml}+\mathrm{dB} . \mathrm{M} \mathrm{MP}^{2}, \\
7 \times 10^{-6} \mathrm{M}\end{array}$ & $\begin{array}{c}8.7 \\
(8.5-8.8)\end{array}$ & & $\cdots$ \\
\hline
\end{tabular}

${ }^{1}$ All experiments were begun after $40 \mathrm{hr}$ in culture, and enzyme activity was analyzed in duplicate $18 \mathrm{hr}$ later. Where two sets of data are available, the mean is followed by the range in parentheses. Standard deviation is given for more than two sets of data. Each figure at 13 days of gestation represents 15-25 pooled livers; each figure at 15 days represents 5.8 pooled livers. ${ }^{2} N^{6}, \mathrm{O}^{2}-$ Dibutyryl cyclic $\Lambda \mathrm{MP}$.

in Figure 3. This pattern was also found with fetal human liver explants, $c . g ., 7$ units/mg protein at $15 \mathrm{hr}$ to 10.2 units $/ \mathrm{mg}$ protein at $10 \mathrm{hr}$ in culture.

The activity of fetal rat liver TTA increased markelly after incubation of the explants with hydrocortisone $\left(10^{-0} \mathrm{M}\right)$, as seen in Figure 1. The activity of I'IA in cultured explants increased significantly after incubation with hydrocortisone in tissues from rats of gestational age 15 days 10 term. No increase wass evident, however, in any of the six determinations each representing 15-25 pooled livers from 13-lay-old fetuses under identical conditions. The size of the rat liver underwent a foufold increase from the 13 th to the 15th day of gestation, and the color of the liver tissue changed from pale grey to red during this time.

Addition of actinomycin I) $(25 \mu \mathrm{g} / \mathrm{ml})$ to the culture medium inhibited completely the hydrocortisone-incluced increase of TTA activity in the fetal rat liver explants when added $4 \mathrm{hr}$ before the steroid (Fig. 3). However, when the explants were incubated with hydrocortisone for $4 \mathrm{~h}$ before the addition of actinomycin, a lesser rise in T'TA activity could be noted. When cycloheximicle wats adcled (10 $\mu \mathrm{g} / \mathrm{ml})$ to the culture medium either $4 \mathrm{hr}$ before or after the steroid, a complete inhibition of the hydrocortisone-induced increase of TTA activity was found.

In adclition to hydrocortisone, incubation of term rat liver explants with glucagon $(5-25 \mu \mathrm{g} / \mathrm{ml})$ and insulin (0.05-0.5 unit/ml), moderately increased T'M activity. The increase after incubation with these pancreatic homones was 2.5-fold and 2.3-fold the control values, respectively (Table II). Pooled livers in culture from 13-daty-old fetuses which did not react by increased TTA activity after incubation with hydrocortisone in previous experiments exhibited a 2 -fold increase in TTA activity when both glucagon and dibutyryl cyclic $A M P$ were added to the culture medium, as seen in Table II.

No increase in TTA activity in any of the 16 human fetal livers was found with any of the agents tested: hydrocortisone $\left(10^{-8}\right.$ to $\left.10^{-4} \mathrm{M}\right)$, triamcinolone $\left(10^{-4}-10^{-3} \mathrm{M}\right)$, insulin $(0.01-0.1$ unit $/ \mathrm{ml})$, glucagon $(1-2.4 \mu \mathrm{g} / \mathrm{ml})$, cyclic AMP $\left(10^{-3} \mathrm{M}\right.$ to $\left.6.5 \times 10^{-3} \mathrm{M}\right)$, or dibutyryl cyclic AMP $\left(7 \times 10^{-7}\right.$ M to $\left.7 \times 10^{-4} \mathrm{M}\right)$. When dibutyryl cyclic AMP was anministered together with hydrocontisone, there was also no effect on the TTA activity in liver explants from human fetuses, as was the case with combinations of glucagon with cyclic AMP or dibutyryl cyclic AMP.

\section{Discussion}

Some attempts were made to find optimal conditions for maintaining fetal liver explants in culture. Adding call serum to the medium or increasing the oxygen concentration of the gas phase to $95 \%$ did not markedly increase incorporation of precursors or change the histological appearance of the explants from fetal rat 
liver. With the human liver explants, however, it was found that a gas phase of $95 \%$ oxygen increased survival. The incorporation of radioactive precursors, the histological appearance, the mitotic inclex, and the fact that the T'IA activity showed a slight increase during the culture period all provide evidence for the viability of the hepatocytes in the fetal liver explants during the experinental period. This confirms the observations mate earlier by Wicks [19].

The rapid rise in TTA activity in rat liver after birth has been found by several investigators $[2,6,17]$. Greengard and Dewey [5] suggested that postnatal hypoglycemia stimulates glucagon release, which then induces liver TTA. Their finding that postnatal injection of glucose decreases the nomal increase of TTA activity is in agreement with this proposal. The failure of adrenalectomized newborn rats to undergo the normal postnatal increase in TTA activity, the induction of T'T by administation of hydrocortisone to these animals [17], and, further, the observation by Franz and Knox [으 that administration of hydrocortisone to newborn rats did not elevate T'TA activity until after the postnatal increase had occured suggest that glucocorticoids apparently also participate in the immediate postnatal increase of 'T' $\mathrm{T} A$ activity.

In the present study a maximal level of TTA activity was reached at about $16 \mathrm{hr}$ after birth; thereafter the enzyme activity clecreased rapidly to attain initial term fetal ralues within about $8 \mathrm{hr}$. The rapid fall in cnzyme activity is consistent with a half-life of the enzyne of $3-4 \mathrm{hr}[10]$, if one assumes that enzyme synthesis stops when the peak postnatal value is reached. The studies by Holten and Kenney [9] indicate that the glucagon-mediated induction of liver TTA ceases despite a continuous administration of the hormone, whereas in the alse of hydrocortisone the elevated enzyme synthesis continues for as long as the steroid is present. The corticosterone concentration in postmatal rat plasma increases considerably above adult levels until $5 \mathrm{hr}$ after delivery [7].

Diflerences have been observed in the effect of certain inducing agents of ITA as related to the developmental age of the rat. Ihus, TTA can be induced in vivo by hydrocortisone administration only in postnatal rats $[3,17,19]$ although it has been shown that the synthetic glucocorticoid. triamcinolone, markedly elevates I IA activity in term fetuses when the exposure time is greater than $10 \mathrm{hr}$ [21]. Other inducing agents such as glucagon, adrenalin, and cyclic AMP act in vizo by elerating liver ITA activity in fetal animals [4], but also a definite developmental trend in the competence to react to these agents has been found. Greengard [3] recently prenented a scheme indicating the development of the competence of the fetal rat liver to respond to gluatagon and cyclic $A M P$ in vizo. Her results demonstrate that the competence of liver to symthesize 'I'IA under the influence of cyclic AMP is present 4 days before birth, but glucagon alone does not induce I'IA at this developmental stage. During the next fetal day the capacity develops to raise the concentration of cyclic AMP on exposure to glucagon and adrenaline, and thus the $\mathrm{T}$ 'T $\Lambda$ activity can be evoked by these homones as well as by cyclic AMP.

Stuclies in ritro on rat liver explants in organ culture $[19,20]$ have shown that term fetal liver can be stimulated to increase synthesis of TTA by glucagon, insulin, and cyclic AMP, and that hydrocortisone is an effective inclucer of $\mathrm{TT}$ A in cultures of liver from 17-day fetuses. Rutter [15, 16] reported that TTA activity (an be stimulated by incubation of fetal rat liver explants in culture with triameinolone at any period during the development of the rat. Thus, it seems evident from the available data that the competence to react by increased TTA activity in response to corticosteroids appears in fetal liver maintained in culture at an earlier developmental stage than in vivo. The results presented in this paper are consistent with this and clemonstrate furthermore that fetal rat liver maintained in organ culture is not competent to respond to hydrocortisone by increasing the TTA activity before day 1:3-14 of gestation, although glucagon and cyclic AMP produce a stimulus at this stage. This finding is in agreement with the hypothesis presented by Kenney st al. [11] that the induction of TTA activity by hydrocortisone is produced by a mechanism different from that of glucagon. Furthermore, Holt and Oliver [8] have recently suggested the existence of multiple forms of rat liver TTA, each of which may be under the incluctive influence of a different agent. This finding is also consistent with the developmental dissimilarities of the induction of this enzyme.

It is clifficult to speculate on the reasons for the nonresponsiveness of early human fetal liver explants to any of the agents examined. We do not believe that this was due to maintenance of the fetal human liver in organ culture since all of the criteria for judging the viability of the tissue indicated that the human tissue was viable. Thus, it appears that explants of human fetal liver of 1.1-2.4 weeks' gestation in organ culture are incompetent to respond by increasing TTA activity to the external chemical stimulants used. 


\section{References and Noles}

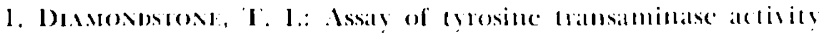

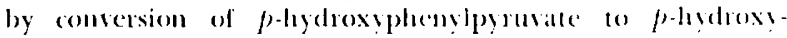
benzoldehyde. Anal. Biochem.. 10: 395 (19666).

2. Fr.anz, J. M., AND $\mathrm{kNox}, \mathrm{W}$. F.: The effect of development and hydrocottisone on tryptophan oxygenase. formamidase. and cyosine aminotransferase in the lisers of young rats. Biochemistry, 6: 3464 (1966).

3. (ikteviant), ().: The hormonal regulation of encymes in prenatal and postmatal rat lives. Elfects of ademosine 3 '5' (c)clic)-monophosphate. Biochem. J., $1 / 5: 19$ (1969).

4. (iRTENGARL, (): Fnzumic differentiation in mammatian liver. Science, 103: 891 (1969).

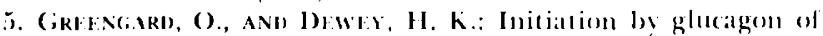
the premature development of tyrosine aminotransferase. scrine dehychatase, and glucose b-phosphatase in fetal rat liver. J. Biol. Chem., 2t2: $2986(196 i 7)$.

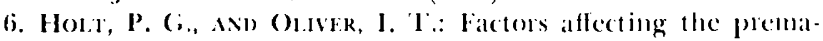
ture induction of tyrosine aminotransferase in foctal rat liver. Biochem. J., I08; 333 (1968).

7. Hol.T, P. G., AND Ot.IVIR, I. I.: Plasma corticosterone concentrations in the perinatal rat. Biochem J., 108 : 339 (I968).

8. Hot, P. (i., AND Olovik, I. I .: Multiple foms of tyrosine aminotransferase in rat liver and their hormonal induction in the neonate. Fed. Fur. Biochem. Sox. Letters, 5: 8!) (19)6!)

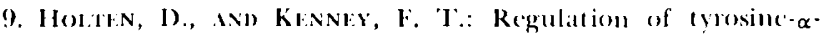
ketoglutanate transaminase in rat liver. VI. Induction by pancreatic hormone's. J. Biol. Chem., 2f2: 4372 (1967).

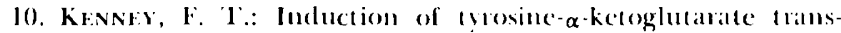
aminase in rat liver. $1 \mathrm{~S}$. Fvidence for an increase in the rate of enzyme synthesis. J. Biol. Chem., 237 : 3495 (1962).

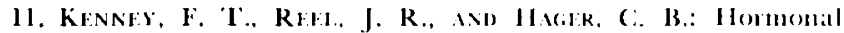
induction and repression. In: Regulatory Mechanisms for Protein Synthesis in Mammalian C(clls, P. 119) (Academic Press, New York, I!688).

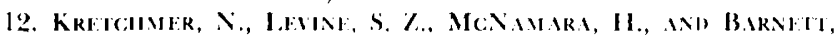
H. L.: Certain aspects of tyosine metabolism in the young. I. The development of the tyrosine oxidlizing ststem in human liver. J. Clin. Invest. 35: 236 (19596).

13. LoWkY, O. H.: Rosfrkot (iH, N. J., Jakk, A. I., AND RAN D.AL., R. J.: Protein measurement with the Folin phenol reagent. J. Biol. Chem., 193: 265) (1951).

14. MaNs, R. J., And Novttit, (;. 1). Measurement of the in. corporation of radioactive amino acids into peotein, by a filter-paper disc method. Arch. Biochem. Biophys., 9.: t8 (1961).

15. Rurrek, W. J.: Independently regulated ssnthetic tratnsitions in foetal tissues. In: Foctal Automomy (Ciba Foundation), p. 59 (J. A. Churchill, London, 1969).

16. RuTter, W. J.: Personal communication to A.I..S.

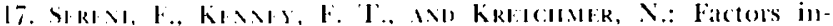
Huencing the develepment of mosine- $\alpha$-ketoglutatate trans-

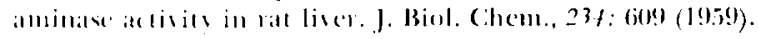

18. I kewtis. (). I.: I modified sechnique for organ culture. kxp. (ivll. Res., o: 216 (1954).

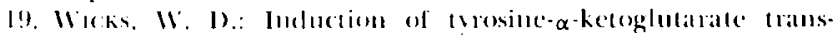
anduase in fetal rat liver. J. Biol. (hem., 2/3: (900) (19)(38).

20). Wishs. W. 1).: Induction of hepatic ensmes by adenosine $3^{\prime}-5^{\prime}-$ monophesphate in organ culture. J. Biol. Chem., 2ft: $3911(199(9)$.

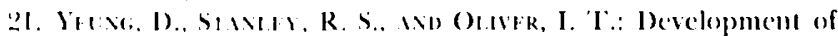
gluconeregenesis in meonatal rat liver. Feflect of triancinolone. Biochem. J.. 165: 1219) (1916i7).

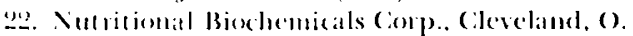

23. Nono Industri a s. (openhagen, 1)emmatk.

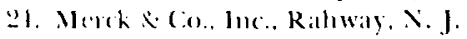

25. Kenacont, Squib), sweden.

26. Sigma (hemical Co.. St. Iouis, Mo.

27. Radienchemical contre, Amersham, England.

2x. Orion ()x, Helsinki, linlancl.

29. Patckildel (comp., Downers (irove, Ill.

30. The anthors atchowledge the excellent fechnical assistance of Mis. ledith 1 ammilehte and the advice and encouragement of Marti Virolajuen, M. 1)., and Professor Laturi saxén, M.l). We atre also grateful to Merck shatp \& Dohme for their gift of atchomscin 1$)$.

31. Supposted bo the Association for the did of crippled (hildren, New Yonk, and sigrid fus:-lius Stiftelse, Helsinki.

32. I preliminars presentation of this material has been pre. sented at the furopean socieds for Pediatric Research Mecting, September, 1969.

33. Presem address: Bepantment of Biology, Case Westem Reserve Iniversits. Cleveland, O. (USA)

34. Reguests for reprints should be addressed to: Niels Räihä, N.1). Depastment of Nedical chemistry, lniversity of Helsinki. Melsinki, Finland.

35. Note: Mfer this paper wats sent to be published we received liser from an immature human fetus delivered in the hospital by spontancous abortion at a gestattional age of 28 weeks. The fotwe died trammatically during breech delivery and liver tissue was immediatedy remosed and explants were cultured acconding to the lechnigue presented in this paper. Criamcinolone $\left(1 \times 10^{-1}\right.$, . 1$)$ produced a fourfolel increase in I"IS activity in these explants from the 28-week fetus (cown to rump length $=25$ (m). The control values after (i2 he in culture were 14.7 and 17.4 mits $m$ m protein, and after incubation with triancinolone the values were 50,0 and 63.0 units my protein. The histological appeatance of the hepatocytes after the incubation period was sattisfactory.

36. Accepted for publication March 24, 1970. 